\title{
Influence of methods of application and concentrations of plant growth regulators on plant growth, flowering, yield and yield attributes in winter chilli (Capsicum annuum L.) cv. PANT C-1
}

\author{
INDU ARORA, J.P.SINGH ${ }^{1}$ AND PRAMOD CHAUHAN ${ }^{2}$
}

\section{Authors' InFo}

Associated Co-author : 'Department of Horticulture, Gochar Mahavidyalaya, SAHARANPUR (U.P.) INDIA

${ }^{2}$ Department of Horticulture, G.B.Pant University of Agriculture and Technology, PANTNAGAR (UTTARAKHAND) INDIA

\author{
Author for correspondence: \\ INDU ARORA \\ D.S.T. Project, Department of \\ Vegetable Science, G.B.Pant \\ University of Agriculture and \\ Technology, PANTNAGAR \\ (UTTARAKHAND) INDIA \\ Email: induarora1984@gmail.com
}

\begin{abstract}
The present investigation was undertaken during winter season at Horticulture Research Farm of Gochar Mahavidhyalaya, Rampur Maniharan, Saharanpur, U.P on chilli cv. Pant C-1 to find out the most suitable concentration, time and method of application of plant growth regulators for growth, flowering, fruit set, yield and yield attributes in winter chilli. Among different concentrations of plant growth regulators, $45 \mathrm{ppm}$ NAA was found superior to all other treatments for improving growth, yield and yield attributes, ). Application of $45 \mathrm{ppm}$ NAA increased number of fruits, fruit length and fruit girth thus resulted in higher red ripened fruit yield in winter chilli cv. Pant C-1.Among methods of application, seedling root dip for 30 minutes along with double spray at flower bud initiation stage and 20 days later to it, was found superior for plant growth, yield and yield attributes studied. Improved yield and yield attributes were observed in treatment combination, $\mathrm{M}_{5} \mathrm{C}_{3}(45 \mathrm{ppm}$ NAA used as seedling root dip for 30 minutes along with double spray) among all the interactions.
\end{abstract}

KEY WORDS : Plant growth regulators, Plant growth, Flowering, Attributes, Chilli (Capsicum aпnиum) cv. PANT C-1

How to cite this paper : Arora, Indu, Singh, J.P. and Chauhan, Pramod (2016). Influence of methods of application and concentrations of plant growth regulators on plant growth, flowering, yield and yield attributes in winter chilli (Capsicum annuum L.) cv. PANT C-1. Adv. Res. J. Crop Improv., 7 (1) : 134137, DOI : 10.15740/HAS/ARJCI/7.1/134-137.

Paper History : Received : 02.02.2016; Revised : 25.04.2016; Accepted : 20.05.2016 